\title{
Designing of multimedia learning using lectora inspire for informatics education students
}

\author{
Elfi Tasrif*) \\ Universitas Negeri Padang, Indonesia
}

\section{Article Info \\ Article history:}

Received Jan $03^{\text {rd }}, 2021$

Revised Feb 06 ${ }^{\text {th }}, 2021$

Accepted Feb 14 $4^{\text {th }}, 2021$

\section{Keyword:}

Design

Learning

Multimedia

Education

Lectora Inspire

\begin{abstract}
Learning is more interesting and helps foster a sense of enthusiasm for learning is the role of multimedia. This study aims to design multimedia learning on the subject of Computer Networks and Data Communication for informatics education students. This type of research uses a development research approach, this research will only focus on stage I, namely designing multimedia learning. Designing multimedia learning in computer networking and data communications subject using Lectora Inspire Software. Furthermore, validation is carried out based on expert trials, on aspects of software engineering, aspects of application design, aspects of visual communication. The results of designing multimedia learning in the subject of Computer Networks and Data Communication for informatics education students are valid, feasible, easy to use, and very friendly. So that with this multimedia learning design greatly contributes to learning in informatics education.
\end{abstract}

Corresponding Author:

Elfi Tasrif,

Universitas Negeri Padang

Email: elfitasrif@ft.unp.ac.id

\section{Introduction}

Engineering education is a higher education system that is directed at the mastery of certain applied skills (Ganefri et al., 2018; Tasrif, 2019b). Furthermore, students are given the opportunity to develop their potential and creativity so that they are expected to have skills according to their expertise (Hidayat., 2015; Jamilah et al., 2019). Higher education is an educational institution that is expected to produce graduates with academic abilities in the scientific field they are engaged in (Hidayat et al., 2018a). Besides having competence in their respective fields, graduates are required to have entrepreneurial spirit and values (Hidayat et al., 2018b; Hidayat, \& Yuliana, 2018; Hidayat et al., 2019b; Hidayat et al., 2019c; Hidayat et al., 2020). It is hoped that graduates who have entrepreneurial competencies can create job opportunities. Therefore, tertiary institutions must always follow the development of science and technology that is developing rapidly in order to absorb and renew, especially on motivation, attitudes and the results of the learning process that takes place in it (Hidayat, 2017a, 2017b; Yulastri, 2018; Hidayat et al., 2019a; Tasrif et al., 2020a).

One of the factors that can support student independence in learning is the availability of adequate learning resources (Almara'beh, Amer, \& Sulieman, 2015; Adekunle, Adewale, \& Boyinbode, 2019; Albariki, Prasetyo, \& Sunarto, 2020). These learning resources can be in the form of textbooks, modules, assignment sheets, lecture dictates, and others. However, it should be noted that the use of learning resources that are routine without variation will certainly not arouse students' interest in independent study (Anmarkrud, Andresen, \& Bråten, 2019). That is what happened to Computer Networks and Data Communications subject. At this time, the subject of computer networks and data communication still uses learning resources in the form of textbooks, causing students to look bored and bored. 
The boredom experienced by students prevents them from thinking creatively so that they only focus on exercises and discussions given by the lecturer in the lecture process (Astatke et al., 2016). This learning pattern result in students being unable to solve problems that are different from the questions and discussions given by the lecturer (Botelho et al., 2016). Student saturation with the use of learning resources that do not vary results in low student motivation. Lectures without the help of multimedia learning can certainly make it difficult for students to visualize abstract concepts (Dalle, Hadi, \& Baharuddin, 2017; Davis, 2018). Therefore, it is necessary to have learning media that is able to concrete the concepts of computer network and data communication materials (Iskandar et al., 2018).

The teaching and learning process is essentially a communication process, namely the process of delivering messages from message sources, through certain channels or intermediaries, to message recipients (Ganefri et al., 2017). In the teaching and learning process, the message is in the form of teaching material delivered by the lecturer, while the channel or intermediary used to deliver teaching material is learning media or also known as instructional media (Kersten, 2018). Learning that occurs in engineering education is closely related to learning media, including interactive media and multimedia (Johnson, Ozogul, \& Reisslein, 2015; Hamada, \& Hassan, 2016; Jiang, Renandya, \& Zhang, 2017; Karabulut- Ilgu, Jaramillo Cherrez, \& Jahren, 2018). Through multimedia, the functions of learning media in the teaching and learning process are to (1) clarify the presentation of messages so that they are not verbalistic, (2) overcome the limitations of space, time, and sensory power, (3) eliminate passive attitudes to learning subjects, (4) aggravate motivation on the subject of learning.

One of the learning media that can be used to solve the above problems is multimedia learning (Drigas, Kokkalia, \& Lytras, 2015; Negara, 2017; Mutlu-Bayraktar, Cosgun, \& Altan, 2019). The use of computers in independent learning is not new but is one of the educational technology innovations in the development of reliable learning media (Wang et al., 2017; Wang et al., 2018; Violante, Vezzetti, \& Piazzolla, 2019). Multimedia learning is one of the innovations of learning that can be used to help solve some of the problems faced in lectures on computer networks and data communication (Zhan, \& So, 2017; Chou, \& Feng, 2019). This learning multimedia can be run offline on a computer with minimal specifications. Learning multimedia are equipped with pictures, sound, and moving pictures or animations that can attract and facilitate students' interest in learning (Milovanovic et al., 2016; Molina et al., 2018; Mawardi, Iriani, \& Daryati, 2019). The design of this learning multimedia uses Lectora Inspire Software (Nursidik, \& Suri, 2018; Umarella, Rahmawati, \& Susilowati, 2019), with the consideration that this software has various advantages compared to other multimedia learning software (Romadhan, \& Rusimamto, 2015).

\section{Method}

Methods for designing of multimedia learning in computer networking and data communications subject for informatics education students, in this study using a research and development approach called Research and Development (Syofii, \& Sari, 2020). Designing of multimedia learning in computer networking and data communications subject using Lectora Inspire Software. Multimedia Learning is carried out in 3 stages, Phase I: Needs Analysis and Designing of Multimedia Learning, Phase II: Evaluating of Multimedia Learning and Developing of Multimedia Learning, Phase III: Implementation of Multimedia Learning and Dissemination. This research will only focus on stage I, namely Designing of Multimedia Learning by involving 93 students taking Computer Networking and Data Communication subjects in engineering education at universities in Padang, Indonesia.

The design stage of multimedia learning (Astutik, \& Rusimamto, 2016), namely: 1) Defining needs; system analysis defines the problem of user needs and determines that the solution requires multimedia; 2) Feasibility study; a study used to determine whether the development of a multimedia system project is feasible or not; 3) Analysis of system requirements; whether the existing system meets the minimum requirements (Ganefri et al., 2017); 4) Designing concepts; System and user analysis may work with communications professionals such as video producers, directors and technicians, involved with drafting concepts that define the overall message and examine major sequences. Concept design is needed as a basis for thought and creativity in accordance with the purpose of making these interactive multimedia applications; 5) Design content; development is reflected in the content design by preparing detailed application specifications. Applications created will be filled with several elements, including images, sound, text, animation and video; 6) Writing the script; dialog or all detailed elements of the specified order. The script design explains the contents of the text, words or sentences contained in the application. This section is needed as an explanation for the program flow and components that the application is designed to design 
and must match, such as a storyboard; 7) Designing graphics; the selected graphic supports the media. The background and equipment that need to be used in designing the media. The form of activity includes the selection of graphics that support the dialogue and the background of the multimedia application facilities to be used; 8) Producing systems; development of the production system of various parts and integrate them with the system; 9) Perform user tests; system analysis educates the user in using the system and provides the opportunity for the user to become familiar with all the features; 10) Using the system; the user uses the system; 11) Maintain the system; like any other computer based system, the multimedia system must be maintained. the main difference is that the user cannot be expected to perform maintenance, maintaining the system is the task of specialists and professionals.

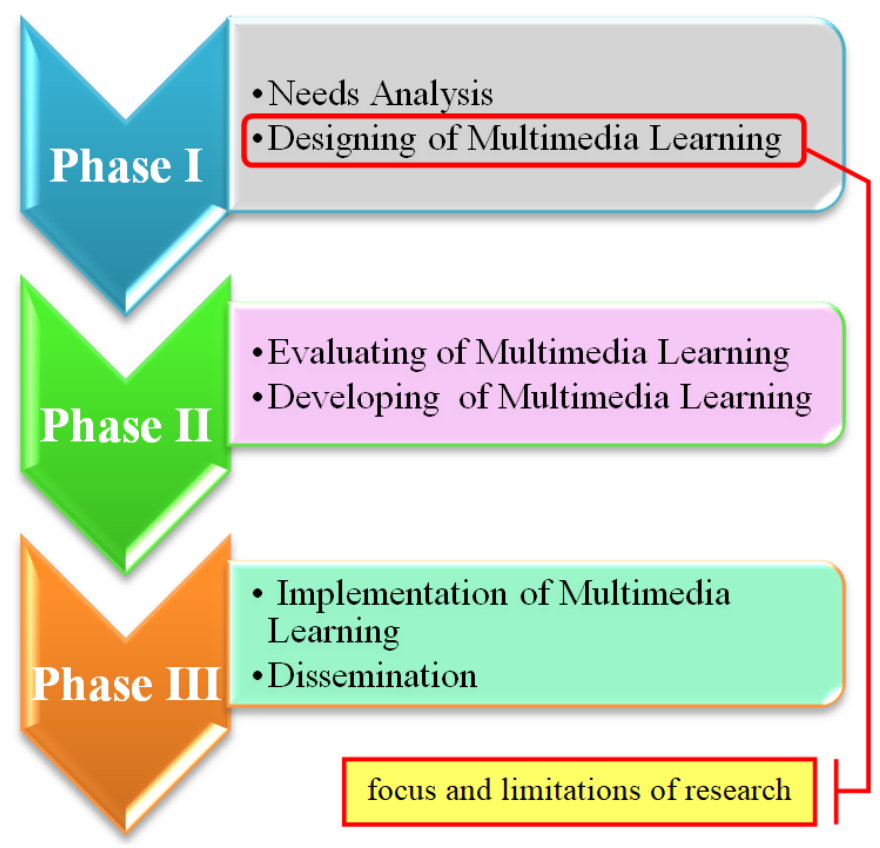

Figure 1. Research focus framework

\section{Results and Discussion}

Engineering education students in higher education are expected to have good competency skills (Kusumaningrum et al., 2016; Rahmadani, Hidayat, \& Syahmaidi, 2018; Syahmaidi et al., 2021), independence, entrepreneurial spirit, (Yulastri, \& Hidayat, 2017; Yulastri et al., 2019) and the ability to survive living in society, this condition requires engineering education students to be more serious in the learning process in higher education (Park, 2015; Tasrif et al., 2021). One alternative to support the learning of engineering education students in tertiary institutions is the design of multimedia learning (Zarei, MohdYusof, \& Daud, 2015; Tasrif, 2019a; Tasrif et al., 2020b; Syah, \& Tasrif, 2021). The use of technology, measurement and innovation in learning has been done a lot of research on the success of this method (Syahmaidi, \& Hidayat, 2016).

The results of designing learning multimedia in the subject of Computer Networking and Data Communications are as follows: 


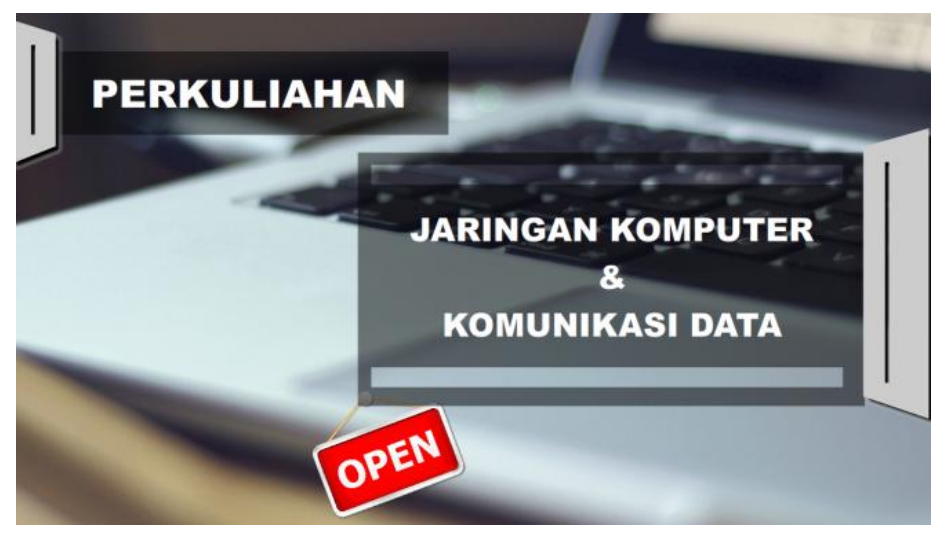

Figure 2. Display of Multimedia Home Page

Learning This page contains information on opening Multimedia. If students click the start button, Multimedia will display the main menu scene.

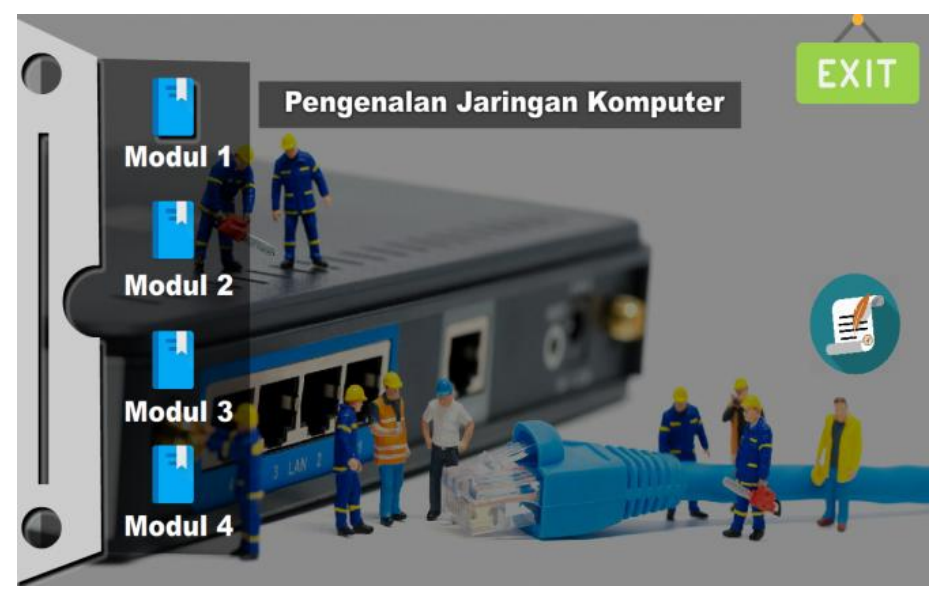

Figure 3. Display of Module Menu

The main menu is a menu that contains buttons which are the main components of this learning multimedia.

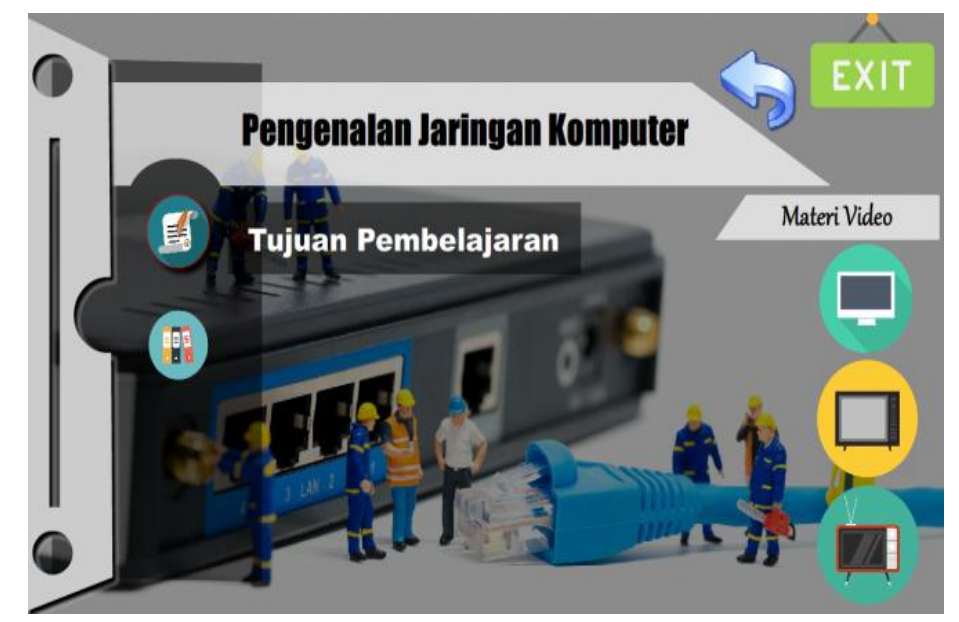

Figure 4. Display of the First Module

This display, displays the components that will be discussed in Module 1. 


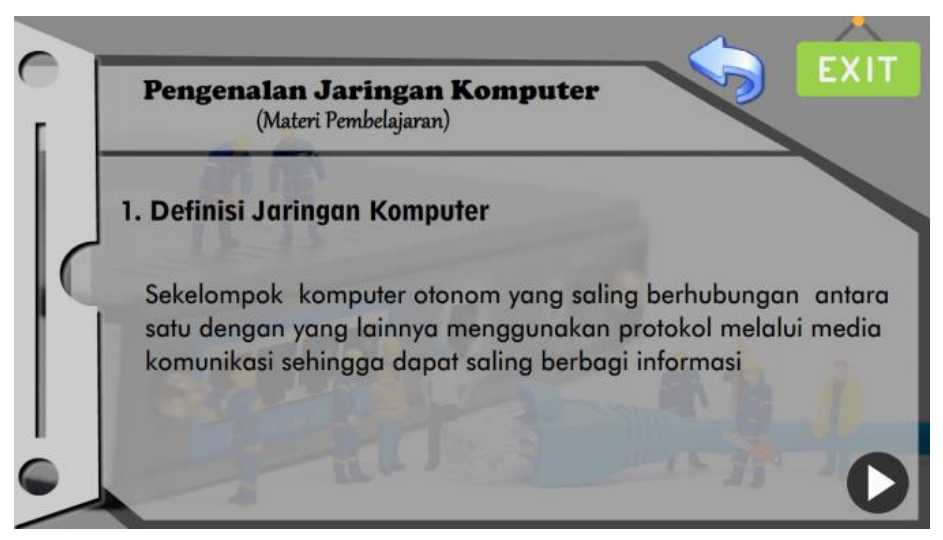

Figure 5. Display of material

In this media, material is not only presented directly to students. The concept is presented through interesting illustrations.

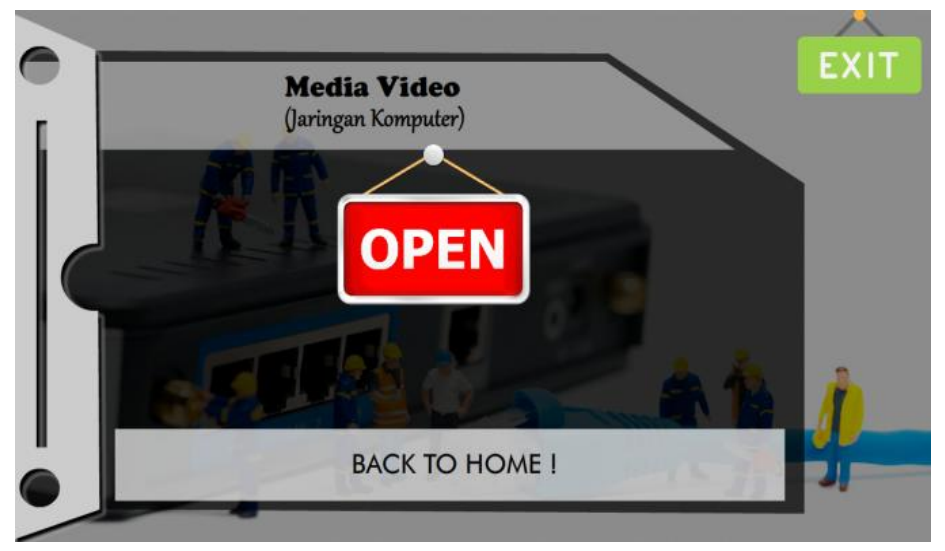

Figure 6. Display of Video Menu

The video menu is packaged in the form of buttons that students can select (click). The videos given vary according to the material shown.

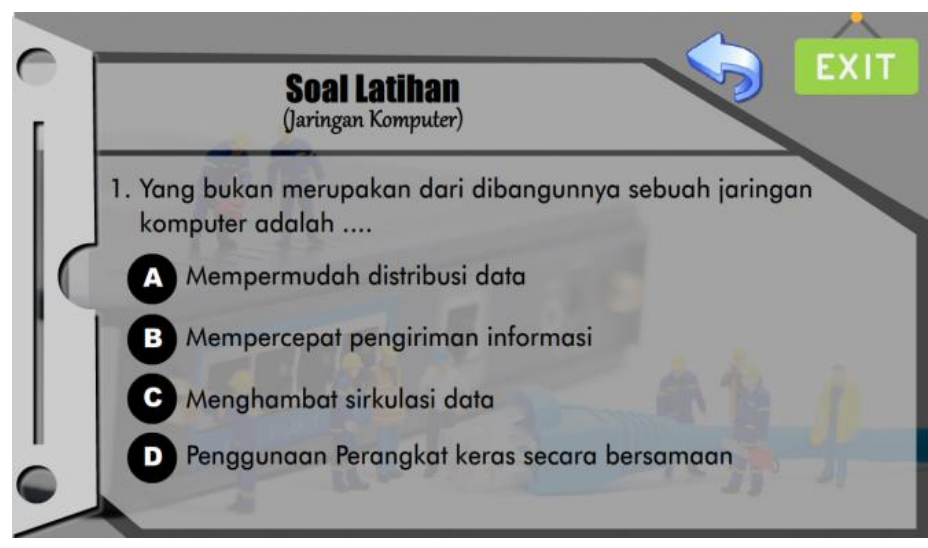

Figure 7. Display of Exercise

Exercises on multimedia can help students understand lecture material. Multimedia learning that has been designed (Simarmata et al., 2018), is then validated by the experts. Validation of multimedia learning was carried out by 2 experts. Learning multimedia ware declared valid after several discussions and improvements were made. The first validation activity was carried out on March 2, 2021 for experts in the Computer Network and Data Communication subject matter and language experts. The improvements made are adjusted to the suggestions given by the experts. The next validation activity is carried out at different times (according to the expert's availability). This activity is carried out to discuss with the experts about the improvements that have been made. Discussions conducted with an expert's related to the 
improvements that have been made get the results that computer-based learning media are valid and can be used in trials.

The questionnaire data from the expert's assessment were described and analyzed qualitatively and quantitatively. The evaluation or validation carried out by the experts on Learning Multimedia includes several aspects, namely: a) Software Engineering Aspects, b) Application Design Aspects, c) Visual Communication Aspects. The process of validation and overall assessment of the product being designed. The results of data analysis of the validation results on Learning Multimedia from experts on Software Engineering Aspects, Application Design Aspects, Visual Communication Aspects. The results of the analysis show that the Aiken's V value is 0.281 , while the assessment range with Aiken's V ranges from 0 to 1. Then the results of expert validation of Learning Multimedia obtained a value of $V=0.281$, so that it can be stated in the valid category. Based on the suggestions given by the experts, revisions were made so that the Learning Multimedia were valid and feasible to be tested.

The results of this study really make a big contribution in the field of engineering education (Tkachuk, Yechkalo, \& Khotskina, 2020), especially learning media (Stanković , Maksimović , \& Osmanović , 2018). Through the support of multimedia learning, informatics education and engineering education can develop rapidly (Salsidu, Azman, \& Pratama, 2018).

\section{Conclusion}

This research produces a product, namely learning multimedia for the subject of Computer Networks and data communication, which is the learning material for students of the informatics engineering students. Learning multimedia are developed through the literature review stage, field observation. The validity of learning multimedia has been assessed by experts who are experts in the field of science, including in the field of multimedia learning design for computer networks and data communication and the field of language and readability who have experience in learning. So that multimedia learning lectures on computer networks and data communication have met the valid criteria. Furthermore, the results of this design also look easy to use and very friendly.

\section{References}

Adekunle, S. E., Adewale, O. S., \& Boyinbode, O. K. (2019). Appraisal on perceived multimedia technologies as modern pedagogical tools for strategic improvement on teaching and learning. International Journal of Modern Education and Computer Science, 10(8), 15.

Albariki, A. Y., Prasetyo, K., \& Sunarto, S. (2020). The Effects of Learning Media Lectora Inspire of Indonesian Plurality Material on the Results of Learning Social Studies Affective Tolerance at the SMPN 1 Krembung. International Journal for Educational and Vocational Studies, 2(4).

Almara'beh, H., Amer, E. F., \& Sulieman, A. (2015). The effectiveness of multimedia learning tools in education. International Journal, 5(12).

Anmarkrud., Andresen, A., \& Bråten, I. (2019). Cognitive load and working memory in multimedia learning: Conceptual and measurement issues. Educational Psychologist, 54(2), 61-83.

Astatke, Y., Ladeji-Osias, J. O., James, P., Moazzami, F., Scott, C., Connor, K., \& Saka, A. (2016). Improving and expanding engineering education in the Middle East and Africa using mobile Learning technology and innovative Pedagogy. In Advances in Engineering Education in the Middle East and North Africa (pp. 235-260). Springer, Cham.

Astutik, M., \& Rusimamto, P. W. (2016). Pengembangan media pembelajaran multimedia interaktif berbantuan software Lectora Inspire untuk meningkatkan hasil belajar pada mata pelajaran teknik listrik di SMK Negeri 2 Surabaya. Jurnal Pendidikan Teknik Elektro, 5(1).

Botelho, W. T., Marietto, M. D. G. B., Ferreira, J. C. D. M., \& Pimentel, E. P. (2016). Kolb's experiential learning theory and Belhot's learning cycle guiding the use of computer simulation in engineering education: A pedagogical proposal to shift toward an experiential pedagogy. Computer Applications in Engineering Education, 24(1), 79-88.

Chou, P. N., \& Feng, S. T. (2019). Using a tablet computer application to advance high school students' laboratory learning experiences: A focus on electrical engineering education. Sustainability, 11(2), 381.

Dalle, J., Hadi, S., \& Baharuddin, H. N. (2017). The development of interactive multimedia learning pyramid and prism for junior high school using macromedia authorware. The Turkish Online Journal of Educational Technology, 16(3), 714-21. 
Davis, R. O. (2018). The impact of pedagogical agent gesturing in multimedia learning environments: A meta-analysis. Educational Research Review, 24, 193-209.

Drigas, A., Kokkalia, G., \& Lytras, M. D. (2015). Mobile and multimedia learning in preschool education. Journal of Mobile Multimedia, 119-133.

Ganefri, Hidayat, H., Kusumaningrum, I., \& Mardin, A. (2017). Needs Analysis of Entrepreneurship Pedagogy of Technology and Vocational Education with Production Based Learning Approach in Higher Education. International Journal of Advanced Science, Engineering and Information Technology, 7, 1701-1707. http://dx.doi.org/10.18517/ijaseit.7.5.1510

Ganefri, G., Hidayat, H., Yulastri, A., Mardin, A., Sriwahyuni, D., \& Zoni, A. A. (2018). Perangkat Pembelajaran Pedagogi Entrepreneurship Dengan Pendekatan Pembelajaran Berbasis Produk di Pendidikan Vokasi. In Prosiding Seminar Nasional \& Internasional, 1(1).

Hamada, M., \& Hassan, M. (2016). A multimedia learning environment for information theory. In 2016 IEEE International Conference on Teaching, Assessment, and Learning for Engineering (TALE) (pp. 55-61). IEEE.

Hidayat, H. (2015). Production based Learning: An Instructional Design Model in the context of vocational education and training (VET). Procedia-Social and Behavioral Sciences, 204, 206-211.

Hidayat, H. (2017a). How is the Application and Design of a Product-Based Entrepreneurship Learning Tools in Vocational Higher Education?. In International Conference on Technology and Vocational Teachers (ICTVT 2017) (pp. 223-228). Atlantis Press.

Hidayat, H. (2017b). Impact of learning with the production-based learning model in vocational school. International Journal of Research in Engineering and Social Sciences, 7(2), 1-6.

Hidayat, H., Herawati, S., Tamin, B. Y., \& Syahmaidi, E. (2018a). How is the practicality of technopreneurship Scientific learning model design in vocational higher education?. International Journal of Scientific Research and Management, 6(09).

Hidayat, H., Herawati, S., Syahmaidi, E., Hidayati, A., \& Ardi, Z. (2018b). Designing of technopreneurship scientific learning framework in vocational-based higher education in Indonesia. International Journal of Engineering and Technology (UAE), 7(4), 123-127.

Hidayat, H., \& Yuliana. (2018). The Influence of Entrepreneurship Education and Family Background on Students' Entrepreneurial Interest in Nutritious Traditional Food Start Ups in Indonesia. International Journal of Engineering and Technology(UAE). 7(4), 118-122. https://doi.org/10.14419/ijet.v7i4.9.20631

Hidayat, H., Tamin, B. Y., Herawati, S., Khairul, K., \& Syahmaidi, E. (2019a). The contribution of technopreneurship scientific learning and learning readiness towards the entrepreneurship learning outcomes in higher vocational education. Jurnal Pendidikan Vokasi, 9(1), 21-32.

Hidayat, H., Ardi, Z., Yuliana, \& Herawati, S. (2019b). Exploration of the need analysis for technopreneurship scientific learning models in higher vocational education. International Journal of Economics and Business Research, 18(3), 356-368.

Hidayat, H., Tamin, B.Y., Herawati, S., Hidayati, A., Muji, A.P. (2019c). Implementation of technopreneurship scientific learning for produce electronic product prototypes in engineering education. International Journal of Innovative Technology and Exploring Engineering, 8(11), 28422846. http://dx.doi.org/10.35940/ijitee.K2406.0981119

Hidayat, H., Tamin, B. Y., Herawati, S., Ardi, Z., \& Muji, A. P. (2020). The Contribution of Internal Locus of Control and Self-Concept to Career Maturity in Engineering Education. Int. J. Adv. Sci. Eng. Inf. Technol, 10(6), 2282-2289.

Iskandar, A., Rizal, M., Kurniasih, N., Sutiksno, D. U., \& Purnomo, A. (2018). The Effects of Multimedia Learning on Students Achievement in Terms of Cognitive Test Results. In Journal of Physics: Conference Series (Vol. 1114, No. 1, p. 012019). IOP Publishing.

Jamilah, Y., Sukardi, S., Tasrif, E., Nendra, F., \& Firdianis, E. (2019). Evaluation Program of Work Practice in Industrial Vocational High School (Seen From Respondents Teacher Supervisor). International Journal of Educational Dynamics, 2(1), 180-187.

Jiang, D., Renandya, W. A., \& Zhang, L. J. (2017). Evaluating ELT multimedia courseware from the perspective of cognitive theory of multimedia learning. Computer Assisted Language Learning, 30(7), 726744.

Johnson, A. M., Ozogul, G., \& Reisslein, M. (2015). Supporting multimedia learning with visual signalling and animated pedagogical agent: Moderating effects of prior knowledge. Journal of Computer Assisted Learning, 31(2), 97-115.

Karabulut-Ilgu, A., Jaramillo Cherrez, N., \& Jahren, C. T. (2018). A systematic review of research on the flipped learning method in engineering education. British Journal of Educational Technology, 49(3), 398411 . 
Kersten, S. (2018). Approaches of engineering pedagogy to improve the quality of teaching in engineering education. In Vocational Teacher Education in Central Asia (pp. 129-139). Springer, Cham.

Kusumaningrum, I., Hidayat, H., Ganefri, Anori, S. \& Dewy, MS. (2016). Learning Outcomes in Vocational Education: a Business Plan Development by Production-Based Learning Model Approach. International Journal of Environmental and Science Education, 11, 1191711930.https://files.eric.ed.gov/fulltext/EJ1122558.pdf

Mawardi, G., Iriani, T., \& Daryati, D. (2019). Pengembangan Media Pembelajaran Berbasis Multimedia Pada Mata Kuliah Kompetensi Pembelajaran Pokok Materi Keterampilan Dasar Mengajar. Jurnal Pensil: Pendidikan Teknik Sipil, 8(1), 24-30.

Milovanovic, M., Perisic, J., Vukotic, S., Bugarcic, M., Radovanovic, L., \& Ristic, M. (2016). Learning mathematics using multimedia in engineering education. Acta Technica Corviniensis-Bulletin of Engineering, 9(1), 45.

Molina, A. I., Navarro, Ó., Ortega, M., \& Lacruz, M. (2018). Evaluating multimedia learning materials in primary education using eye tracking. Computer Standards \& Interfaces, 59, 45-60.

Mutlu-Bayraktar, D., Cosgun, V., \& Altan, T. (2019). Cognitive load in multimedia learning environments: A systematic review. Computers \& Education, 141, 103618.

Negara, I. K. R. Y. (2017). The effect of animation in multimedia computer-based learning and learning style to the learning results. Turkish Online Journal of Distance Education, 18(4), 177-190.

Nursidik, H., \& Suri, I. R. A. (2018). Media pembelajaran interaktif berbantu software Lectora Inspire. Desimal: Jurnal Matematika, 1(2), 237-244.

Romadhan, A., \& Rusimamto, P. W. (2015). Pengembangan Media Pembelajaran Menggunakan Multimedia Interaktif Lectora Inspire Pada Mata Pelajaran Teknik Elektronika Dasar Di SMK Negeri 3 Jombang. Jurnal Pendidikan Teknik Elektro, 4(2).

Salsidu, S. Z., Azman, M. N. A., \& Pratama, H. (2018). Trend Pembelajaran Menggunakan Multimedia Interaktif Dalam Bidang Pendidikan Teknikal: Satu Sorotan Literatur. Sains Humanika, 10(3).

Simarmata, J., Dharma, M., Putra Nasution, T., Manurung, R. T., Lubis, M. A., Kurniasih, N., \& Rahim, R. (2018). Prototype application multimedia learning for teaching basic English. Int. J. Eng. Technol, 7(2.12), 264-266.

Stanković, Z., Maksimović, J., \& Osmanović, J. (2018). Cognitive theories and paradigmatic research posts in the function of multimedia teaching and learning. International Journal of Cognitive Research in Science, Engineering and Education, 6(2), 107.

Syofii, I., \& Sari, D. P. (2020). Development Of Interactive Multimedia Using Lectora Inspire For Vehicle Body Construction Courses In UNIVERSITAS SRIWIJAYA. Journal of Mechanical Science and Engineering, 7(2), 7-9.

Tkachuk, V., Yechkalo, Y., \& Khotskina, S. (2020). Selection of Mobile ICT for Learning Informatics of Future Professionals in Engineering Pedagogy.

Umarella, S., Rahmawati, A., \& Susilowati, N. E. (2019). Interactive multimedia lectora inspire based on problem based learning: development in the optical equipment. In Journal of Physics: Conference Series (Vol. 1155, No. 1, p. 012011). IOP Publishing.

Violante, M. G., Vezzetti, E., \& Piazzolla, P. (2019). Interactive virtual technologies in engineering education: Why not $360^{\circ}$ videos?. International Journal on Interactive Design and Manufacturing (IJIDeM), 13(2), 729-742.

Wang, F., Li, W., Xie, H., \& Liu, H. (2017). Is pedagogical agent in multimedia learning good for learning? A meta-analysis. Advances in Psychological Science, 25(1), 12-28.

Wang, F., Li, W., Mayer, R. E., \& Liu, H. (2018). Animated pedagogical agents as aids in multimedia learning: Effects on eye-fixations during learning and learning outcomes. Journal of Educational Psychology, 110(2), 250.

Park, S. (2015). The effects of social cue principles on cognitive load, situational interest, motivation, and achievement in pedagogical agent multimedia learning. Journal of Educational Technology \& Society, 18(4), 211-229.

Rahmadani, A. F., Hidayat, H., \& Syahmaidi, E. (2018). Design of Electronic Elementary Material Learning Module on Vocational Higher Education. International Journal of Scientific Research and Management, 6(01).

Syah, A., \& Tasrif, E. (2021). Adriansyah Sistem Pembelajaran Berbasis Teknologi Informasi Dan Komunikasi "Studi Kasus MAS TI Canduang dengan Menggunakan Media Pembelajaran Google Classroom". JAVIT: Jurnal Vokasi Informatika, 10-15.

Syahmaidi, E., \& Hidayat, H. (2016). Praktikalitas Perancangan Media e-Learning Berbasis Video. Jurnal Nasional Pendidikan Teknik Informatika: JANAPATI, 5(2), 87-97. 
Syahmaidi, E., Hidayat, H., Hartanto, S., \& Rahmadani, A. F. (2021). Designing E-Training Computer Assisted Instruction Used to Pedagogic Competency in Vocational Education. In Journal of Physics: Conference Series (Vol. 1779, No. 1, p. 012038). IOP Publishing.

Tasrif, E. (2019a). Kajian Keterandalan Penggunaan Media Interaktif Berbasis Mobile. Jurnal Kapita Selekta Geografi, 2(7), 86-96.

Tasrif, E. (2019b). Academic Supervision Mechanism by Vocational High School Supervisor. In 5th UPI International Conference on Technical and Vocational Education and Training (ICTVET 2018) (pp. 160-164). Atlantis Press.

Tasrif, E., Kurnia, H., Pahtoni, T. Y., Kurniadi, D., \& Hadi, A. (2020a). Analysis of Development Needs of Foster Parents Communication Media in Supporting Improvement of Academic Achievement of Students with Weak Socio-Economic Background. In The 1st Progress in Science and Technology Research Symposium. Redwhite Press.

Tasrif, E., Mubai, A., Huda, A., \& Rukun, K. (2020b). Pemanfaatan media pembelajaran berbasis augmented reality menggunakan aplikasi Ar_Jarkom pada mata kuliah instalasi jaringan komputer. Jurnal Konseling dan Pendidikan, 8(3), 217-223.

Tasrif, E., Saputra, H. K., Kurniadi, D., Hidayat, H., \& Mubai, A. (2021). Designing Website-Based Scholarship Management Application for Teaching of Analytical Hierarchy Process (AHP) in Decision Support Systems (DSS) Subjects. International Journal of Interactive Mobile Technologies, 16(9).

Yulastri, A., \& Hidayat, H. (2017). Developing an Entrepreneurship Module by Using Product-Based Learning Approach in Vocational Education. International Journal of Environmental and Science Education, 12(5), 1097-1109.

Yulastri, A., Hidayat, H., Ganefri, G., Edya, F., \& Islami, S. (2018). Learning outcomes with the application of product based entrepreneurship module in vocational higher education. Jurnal Pendidikan Vokasi, 8(2), $120-131$.

Yulastri, A., Hidayat, H., Ganefri, Ayu, R., \& Ardi, Z. (2019). An Empirical Study on The Effects of Pedagogy Learning Tools Entrepreneurship With Product-Based Learning Approach, Learning Readiness, and Locus of Control: A Case From Engineering Education in Indonesia. International Journal of Scientific \& Technology Research, 8(9), 1722-1727.

Zarei, A., Mohd-Yusof, K., \& Daud, M. F. (2015). Mobile multimedia instruction for engineering education: Why and how. ASEAN Journal of Engineering Education, 2(1).

Zhan, Y., \& So, W. W. M. (2017). Views and practices from the chalkface: Development of a formative assessment multimedia learning environment. Technology, Pedagogy and Education, 26(4), 501-515. 